\title{
Phosphorus fertilization associated to inoculation of maize with diazotrophic bacteria
}

\author{
Adriano Mitio Inagaki ${ }^{1 *}$, Vandeir Francisco Guimarães ${ }^{1 \#}$, Luan Fernando Ormond Sobreira \\ Rodrigues $^{2}$, Mônica Bartira da Silva ${ }^{2}$, Marla Sílvia Diamante ${ }^{1}$, Leandro Rampim ${ }^{1}$, \\ Thaísa Muriel Mioranza ${ }^{1}$ and José Barbosa Duarte Júnior ${ }^{1}$ \\ ${ }^{1}$ State University of West Parana, Unioeste, CCA/PPGA, Pernambuco Street No. 1777, P. O. Box 9, Zip Code 85960- \\ 000, City of Marechal Candido Rondon, Parana State, Brazil. \\ ${ }^{2}$ State University Paulista Júlio de Mesquita Filho - UNESP, Lageado Farm, Alcides Soares Highway, Km 3, Zip Code \\ 18610-300, City of Botucatu, São Paulo State, Brazil.
}

Received 31 August, 2014; Accepted 10 October, 2014

\begin{abstract}
The effects of diazotrophic bacteria inoculation associated to phosphate fertilization on plant growth and leaf gas exchange parameters in maize plants (Zea mays L.) were investigated in the present study. Maize plants were grown in 13-L pots filled with clayey Rhodic Hapludox in a greenhouse. Treatments were arranged in a randomized block design in a $4 \times 2$ factorial: four seed inoculation treatments [control (non-inoculated); inoculation with Azospirillum brasilense strain AbV5; inoculation with Herbaspirillum seropedicae strain SmR1; and inoculation with two bacteria strains $(A$. brasiliense $+H$. seropedicae)] and two phosphate fertilization levels [no fertilized or fertilized with phosphorus (300 mg $\mathrm{dm}^{-3}$ of $\left.\mathrm{P}_{2} \mathrm{O}_{5}\right)$ ]. Phosphorus fertilization resulted in higher plant height, stem diameter, number of leaves per plant, leaf area, dry matter yield of leaves, stems and sheaths of maize plants, regardless of seed inoculation with diazotrophic bacteria. Seed inoculation with $A$. brasilense and $H$. seropedicae increased in $42 \%$ of the volume root, in $52 \%$ of the root dry matter and $25 \%$ of the plant height of maize, indicating an increase in the phosphorus solubilization or higher phosphorus use provided by the maize root system. Seed inoculation with $A$. brasilense associated to phosphorus fertilization increased in $\mathbf{2 3} \%$ of the relative chlorophyll content, resulting in higher metabolic structure to the photosynthetic activity of maize plants. The leaf $\mathrm{CO}_{2}$ assimilation rate was not affected by the phosphorus fertilization and maize seed inoculation with $A$. brasilense and $H$. seropedicae.
\end{abstract}

Key words: Plant growth promoting bacteria, phosphate solubilization, gas exchange, Azospirillum brasilense, Herbaspirillum seropedicae, Zea mays.

\section{INTRODUCTION}

The maize culture (Zea mays L.), is the grain species most cultivated in Brazil and in the world, followed by the wheat culture (USDA, 2014; IBGE, 2014). The Brazilian production reached 85.5 million tons of grain, with grain

*Corresponding a uthor. E-mail: mitioinagaki@gmail.com

\#Resea rcher on produc tivity at CNPq.

Author(s) agree that this artic le remain permanently open access under the terms of the $\underline{C r e a t i v e ~ C o m m o n s ~ A t t r i b u t i o n ~}$ License 4.0 Intemational License 
yield of 5.1 ton ha ${ }^{-1}$ in 15.8 million of hectares (CONAB, 2014) and 968.8 million tons in the world (USDA, 2014). In Brazil, the study of biological nitrogen fixation (BNF) in grasses was initiated by Döbereiner (1953), detecting Azotobacter in acid soil of "Baixada Fluminense". Thereafter, the studies were extended with associative bacteria in sugar cane (Döbereiner and Ruschel, 1958) and Paspalum notatum cv. Batatais (Döbereiner, 1966).

Initially, these ones were called diazotrophic bacteria (DB) due the acting in the conversion of atmospheric nitrogen $(\mathrm{N})$ in assimilable $\mathrm{N}$ to plants (Döbereiner and De-Polli, 1980), and can act with plant growth promoting bacteria (PGPB) (Strzelczyk et al., 1994; Carvalho et al., 2009). Indeed, there are studies relating benefits in the accumulation of dry weight of leaves (Rodrigues et al., 2014 ), shoot growth and increased of $7 \%$ in grain yield (Dartora et al., 2013), obtained through the inoculation with AbV5 strain of Azospirillum brasilense in maize culture. The improvement of these agronomic parameters are related to auxin, gibberellin (Strzelczyk et al., 1994) and ethylene production by bacteria; (Strzelczy and Pokojska-Burdziej, 1984). Recently, the solubilization ability of phosphate in soil by DB e PGPB has been demonstrated (Jain et al., 2010; Baldotto et al., 2012; Walpola and Yoon, 2013).

And to ensure the maximum genotypic production of a maize plant, high dosage of phosphorus fertilization is required in addition to nitrogen fertilization divided in three applications from sowing to phenological stage stadium $V_{8}$ (Coelho et al., 1995). In that sense, with several benefits in plants proportionated by associative bacteria, the use of agricultural inputs as principal source of nitrogen and phosphorus, can be reduced.

The phosphorus $(P)$ is macronutrients that have important compounds in the active photosynthetic cells, directly influencing the gas exchange of plants, in both the photosynthesis and cellular respiration process. The photosynthesis is carried out through chlorophyll molecules contained in organelles called chloroplasts, which are activated by luminous energy, transforming it in chemical energy, stored in phosphate compounds such as adenosine triphosphate (ATP) (Taiz and Zeiger, 2013). During the night this action does not occur, however, it occurs only during breath, the reverse process where the plants release $\mathrm{CO}_{2}$ and consume oxygen, consuming ATP (Taiz and Zeiger, 2013).

The gas exchange by maize plants are carried out in the mesophyll of leaves through stomatal openings. It is possible due to the difference of water and $\mathrm{CO}_{2}$ concentration between the internal and external environment of leaves. At the higher water concentration gradient than $\mathrm{CO}_{2}$ gradient, it results in higher water flow than $\mathrm{CO}_{2}$ in the stomata (Farquhar and Raschke, 1978). In that sense, the interference begins in stomatal conductance $\left(g_{s}\right)$, affecting the transpiration $(E)$ and net $\mathrm{CO}_{2}$ assimilation rate $(A)$ (Cowan and Troughton, 1971).

In view of the above, the aim of this study was to evaluate the influence of inoculation with $A$. brasilense
AbV5 and Herbaspirillum seropedicae SmR1 species in maize culture, conducted with and without phosphorus fertilization.

\section{MATERIALS AND METHODS}

An experiment was conducted in a greenhouse in Marechal Cândido Rondon, Paraná State, Brazil $\left(24^{\circ} 46^{\prime} \mathrm{S}, 54^{\circ} 22^{\prime} \mathrm{W}\right.$, and altitude of $400 \mathrm{~m})$, in 13-L plastic pots. The soil was a Rhodic Hapludox (Red Latosol in the Brazilian classification) with $720 \mathrm{~g} \mathrm{~kg}^{-}$ ${ }^{1}$ of clay, $110 \mathrm{~g} \mathrm{~kg}^{-1}$ of silt, and $170 \mathrm{~g} \mathrm{~kg}^{-1}$ of sand. Samples were taken from the surface layer $(0$ to $0.20 \mathrm{~m})$, air dried, sieved through a $2 \mathrm{~mm}$ mesh, and analyzed as in Embrapa (2009). Soil chemical analysis showed $\mathrm{pH}\left(\mathrm{CaCl}_{2} 0.01 \mathrm{~mol} \mathrm{~L}^{-1}\right): 4.8,12.3 \mathrm{~g} \mathrm{dm}^{-3}$ of organic matter, $32 \mathrm{mg} \mathrm{dm}^{-3}$ of $\mathrm{P}$ (Mehlich-1), $3.87 \mathrm{cmol}_{\mathrm{c}} \mathrm{dm}^{-3}$ of $\mathrm{H}+$ $\mathrm{Al}, 0.58 \mathrm{cmol}_{\mathrm{c}} \mathrm{dm}^{-3}$ of $\mathrm{K}, 2.45 \mathrm{cmol}_{\mathrm{c}} \mathrm{dm}^{-3}$ of $\mathrm{Ca}, 0.95 \mathrm{cmol}_{\mathrm{c}} \mathrm{dm}^{-3}$ of $\mathrm{Mg}, 7.85 \mathrm{cmol}_{\mathrm{C}} \mathrm{dm}^{-3}$ of CEC, $51 \%$ of soil base saturation, $4.10 \mathrm{mg}$ $\mathrm{dm}^{-3}$ of $\mathrm{Cu}, 3.00 \mathrm{mg} \mathrm{dm}^{-3}$ of $\mathrm{Zn}, 45.0 \mathrm{mg} \mathrm{dm}^{-3}$ of $\mathrm{Mn}$ and $59.1 \mathrm{mg}$ $\mathrm{dm}^{-3}$ of $\mathrm{Fe}$.

The experiment was arranged in a randomized block design, using four treatments for the seed inoculation factor [control (noninoculated); inoculation with $A$. brasilense strain AbV5; inoculation with $H$. seropedicae strain SmR1; and inoculation with two bacteria strains $(A$. brasiliense $+H$. seropedicae)] and two levels for the phosphorus fertilization factor [no fertilized or fertilized with phosphorus (300 mg dm ${ }^{-3}$ of $\left.\mathrm{P}_{2} \mathrm{O}_{5}\right)$ ], considering a factorial arrangement $(4 \times 2)$. A total of 32 pots were used - four pots per treatment. Maize seeds were inoculated with $4.0 \mathrm{~mL}$ of inoculant for each thousand seeds and then maintained at rest for twelve hours in the shade. Inoculants were provided by the Biochemistry and Molecular Biology Laboratory, Federal University of Paraná (UFPR), Curitiba, Brazil and had concentration of $2 \times 10^{7} \mathrm{CFU} \mathrm{\textrm {mL } ^ { - }}$ . The $P$ source used was simple superphosphate $\left(18 \% \mathrm{P}_{2} \mathrm{O}_{5} ; 25 \%\right.$ $\mathrm{CaO}$ and $12 \% \mathrm{~S})$. The basic fertilization was carried out with applying $30 \mathrm{mg} \mathrm{dm}^{-3}$ of $\mathrm{N}$ as urea $(45 \% \mathrm{~N}), 100 \mathrm{mg} \mathrm{dm}^{-3}$ of $\mathrm{K}$ as potassium chloride $\left(60 \% \mathrm{~K}_{2} \mathrm{O}\right)$ and $40 \mathrm{mg} \mathrm{dm}^{-3}$ of $\mathrm{S}$ as gypsum $(13 \% \mathrm{~S}$ and $18 \% \mathrm{Ca})$. The fertilizer amount applied was performed according to the recommendations for greenhouse crops as described by Alvarez and Fonseca (1990).

Six seeds of maize (Z. mays L., PIONEER 30F53H hybrid) were sown in pots, and four days after seedling emergence, they were thinned to three plants per pot. The soil water content was maintained near at the field capacity with two daily irrigations.

During the growth and development of maize plants were measured using biometric variables. Maize plant height (from the soil surface to the apex of the plants) was measured at $7,14,21$, 41 and 52 days after sowing (DAS). Chlorophyll readings were made using a SPAD meter (SPAD $502^{\circledR}$ Minolta) at 21 and 52 DAS, on the third fully expanded leaf from the apex of the three plants in each pot. The stem diameter $(\mathrm{mm})$ and number of leaves per plant were measured only at 52 DAS.

Leaf gas exchange was monitored with an infrared gas analyzer (LI-6400XT, LICOR, Inc. USA), in the maize growing stage of eight developed leaves - V5 (50 DAS). Measurements of leaf $\mathrm{CO}_{2}$ assimilation rate $\left(A\right.$, in $\left.\mu \mathrm{mol} \mathrm{CO}_{2} \mathrm{~m}^{-2} \mathrm{~s}^{-1}\right)$, transpiration rate $(E$, in $\left.\mathrm{mmol} \mathrm{H}_{2} \mathrm{O} \mathrm{m} \mathrm{m}^{-2} \mathrm{~s}^{-1}\right)$, stomatal conductance $\left(g_{\mathrm{s}}, \mathrm{mol} \mathrm{m}^{-2} \mathrm{~s}^{-1}\right)$ and intercellular $\mathrm{CO}_{2}$ concentration $\left(\mathrm{Ci}\right.$, in $\left.\mu \mathrm{mol} \mathrm{mol}^{-1}\right)$ were taken at 10:00 and 22:00 $\mathrm{h}$, allowing estimation of leaf respiration rate of maize plants. Water-use efficiency - WUE $(A / E)$ was also calculated. At 10:00 h (10:00 am), the gas exchange parameters were determined at $400 \mu \mathrm{mol} \mathrm{mol}{ }^{-1}$ of $\left[\mathrm{CO}_{2}\right]$ and $1500 \mu \mathrm{mol} \mathrm{m} \mathrm{m}^{-1}$ of photosynthetic photon flux density (PPFD), with standard deviation of 0.7444 . The mean photons density of the external environment provided by the apparatus was $716.35 \mu \mathrm{mol} \mathrm{m} \mathrm{m}^{-2} \mathrm{~s}^{-1}$, $48.97 \%$ relative humidity, and air flow of $499.43 \mathrm{~mL}$ per minute. In the evaluation at $22: 00 \mathrm{~h}(10: 00 \mathrm{pm})$, the gas exchange parameters 
Table 1. Analysis of variance for plant height at 7, 14, 21, 41 and 52 days after sowing (DAS), plant hybrid corn seed via $30 \mathrm{~F} 53 \mathrm{H}$ inoculated with plant growth promoting bacteria as a function of phosphate fertilizer ${ }^{1}$.

\begin{tabular}{lccccc}
\hline \multirow{2}{*}{ Source of variation } & \multicolumn{5}{c}{ Mean square } \\
\cline { 2 - 6 } & Height 7 DAS & Height 14 DAS & Height 21 DAS & Height 41 DAS & Height 52 DAS \\
\hline P fertilization & $0.38^{\text {ns }}$ & $34.05^{* *}$ & $869.65^{* *}$ & $7310.52^{* *}$ & $5447.07^{*}$ \\
Inoculation & $0.20^{\text {ns }}$ & $3.84^{\text {ns }}$ & $0.31^{\text {ns }}$ & $128.01^{\text {ns }}$ & $275.41^{\text {ns }}$ \\
Interaction & $0.91^{\text {ns }}$ & $2.73^{\text {ns }}$ & $143.81^{* *}$ & $524.16^{\text {ns }}$ & $360.98^{\text {ns }}$ \\
Residual & 0.32 & 2.61 & 19.16 & 414.03 & 689.35 \\
\hline C.V. (\%) & 6.46 & 7.58 & 15.87 & 32.98 & 28.89 \\
Average & 8.79 & 21.34 & 27.59 & 61.70 & 91.48 \\
\hline
\end{tabular}

$1^{*}=\mathrm{P} \leq 0.05 ;{ }^{* *}=\mathrm{P} \leq 0.01 ; \mathrm{ns}=$ Not significant, by Tukey's test Fisher-Snedecor.
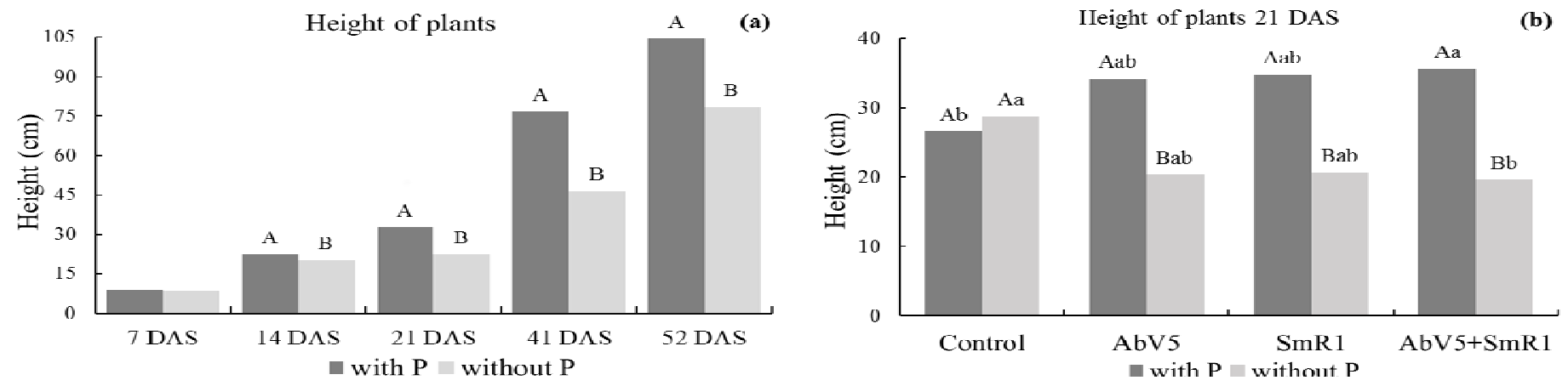

Figure 1. Height of plants at 7, 14, 21, 41, and 52 days after sowing (DAS) the average of the inoculation treatments (a) 1 and height of plants inoculated with control treatment, Azospirillum brasilense, Herbaspirillum seropedicae and association of two species at 21 DAS $(b)^{2}$, depending on the phosphate fertilizer ${ }^{1}$. ${ }^{1}$ Means followed by different letters UPPERCASE comparing phosphate fertilizer in plant height, differ significantly by the Tukey test at $5 \%$; ${ }^{2}$ Means followed by the same letter LOWERCASE comparing phosphorus fertilization in seed inoculation and seed inoculation UPPERCASE comparing within phosphate levels do not differ significantly by the Tukey test at $5 \%$.

were measured in dark room (no photons) with $400 \mu \mathrm{mol} \mathrm{mol}{ }^{-1}$ of $\left[\mathrm{CO}_{2}\right], 44.95 \%$ relative humidity, and air flow of $499.39 \mathrm{~mL}$ per minute. At 52 days after sowing, the plants in all treatments were harvested and separated into roots, stems, sheaths and leaves. The plant parts were dried in air-forced oven at $65^{\circ} \mathrm{C}$ for three days, and then weighed.

The leaf area (LA, $\mathrm{dm}^{2} / \mathrm{pot}$ ) was determined using the following equation proposed by Benincasa (2003):

$\mathrm{LA}=[(\mathrm{LAs} \times \mathrm{TDML}) / \mathrm{DMs}]$

where LAs is the leaf area of the sample collected, TDML is the total dry matter of leaf and DMs is the dry matter of the sample collected. Root volume (RV, $\mathrm{cm}^{3}$ pot $^{-1}$ ) was determined by water displacement using a calibrated cylinder.

Data were analyzed by ANOVA, and the means of phosphorus application and seed inoculation treatments were compared by $F$ test and Tukey test, respectively, both at the 0.05 level of confidence. All analyses were performed using Sisvar 5.1 software for Windows (Statistical Analysis Software, UFLA, Lavras, MG, BRA) (Ferreira, 2011).

\section{RESULTS AND DISCUSSION}

Plant height at 7 days after sowing (DAS) was not affected by phosphate fertilization and inoculation of maize seeds with diazotrophic bacteria (Table 1). This absence of plant height response to phosphorus fertilization and diazotrophic bacteria inoculation was due to the nutrients needed for seedling which are being supplied by the proviso contained in the seeds (Marcos Filho, 2005). At 7, 14, 21, 41 and 52 DAS, the highest maize plant height was obtained in the treatment with phosphorus fertilization, regardless of seed inoculation with diazotrophic bacteria (Figure 1a).

At 21 DAS there was significant interaction between phosphorus fertilization and inoculation of maize seeds with diazotrophic bacteria. The phosphorus fertilization associated to inoculation of maize with $A$. brasilense and $H$. seropedicae resulted in higher plant height compared to the control treatment. Inoculation of $A$. brasilense and $H$. seropedicae isolated or associated showed similar maize height. However, when there was no phosphorus application, maize response was different (Figure 1b). When maize plants were not fertilized with phosphorus, the diazotrophic bacteria provided lower values of plant height at 21 DAS, and associated inoculation of $A$. brasilense and $H$. seropedicae provided maize plants of 
Table 2. Analysis of variance for stem diameter (SD), root volume (RV), number of leaves (NL), leaf area (LA), relative chlorophyll content (SPAD) at 21 and 52 days after sowing (DAS), leaf dry weight (LDW), stem+sheaths dry weight (SSDW) and roots (RDW) of hybrid corn plants via seed $30 \mathrm{~F} 53 \mathrm{H}$ inoculated with plant growth promoting bacteria as a function of phosphate fertilizer'.

\begin{tabular}{|c|c|c|c|c|c|c|c|c|c|}
\hline \multirow{2}{*}{$\begin{array}{l}\text { Source of } \\
\text { variation }\end{array}$} & \multicolumn{9}{|c|}{ Mean square } \\
\hline & SD & RV & NL & LA & SPAD 21 & SPAD 52 & LDW & SSDW & RDW \\
\hline P fertilization & $269.17^{\star *}$ & $105800.00^{* *}$ & $4.48^{*}$ & $91.91^{* *}$ & $131.62^{*}$ & $18.76^{\text {ns }}$ & $187.49^{* *}$ & $307.36^{\star *}$ & $130.17^{* *}$ \\
\hline Inoculation & $3.31^{\mathrm{ns}}$ & $2937.50^{\mathrm{ns}}$ & $1.29^{\mathrm{ns}}$ & $1.24^{\mathrm{ns}}$ & $4.91^{\mathrm{ns}}$ & $28.83^{\text {ns }}$ & $2.18^{\mathrm{ns}}$ & $36.74^{\mathrm{ns}}$ & $3.29^{\mathrm{ns}}$ \\
\hline Interaction & $41.98^{\text {ns }}$ & $20708.33^{\star \star}$ & $1.13^{\mathrm{ns}}$ & $9.39^{\mathrm{ns}}$ & $99.12^{*}$ & $33.06^{\text {ns }}$ & $21.52^{\mathrm{ns}}$ & $6.51^{\mathrm{ns}}$ & $30.79^{* *}$ \\
\hline Residual & 18.05 & 3252.98 & 1.57 & 5.91 & 26.51 & 11.56 & 10.08 & 21.68 & 4.4 \\
\hline C.V. (\%) & 29.32 & 36.95 & 17.96 & 46.16 & 17.64 & 10.87 & 46.97 & 62.75 & 43.25 \\
\hline Average & 14.49 & 154.37 & 6.99 & 5.27 & 29.19 & 31.28 & 6.76 & 7.41 & 4.85 \\
\hline
\end{tabular}

${ }^{1 *}=\mathrm{P} \leq 0.05 ;{ }^{* *}=\mathrm{P} \leq 0.01 ; \mathrm{ns}=$ Not significant, by Tukey's test Fisher-Snedecor.

smaller stature compared to the uninoculated control. The association of $A$. brasilense (a facultative endophytic bacteria) and $H$. seropedicae (an obligate endophytic bacteria) inoculation (Baldani and Baldani, 2005), have direct influence on the height of maize plants. The diazotrophic bacteria may have used the soil available $P$ as support for its maintenance and development, favoring the associative characteristic to plants, in this case, maize under $\mathrm{P}$ fertilization.

Furthermore, several bacterial strains, particularly those belonging to the genera Azospirillum, Bacillus, Pseudomonas and Rhizobium have been described and investigated in detail for their phosphate-solubilizing capabilities from the organic and inorganic soil pools (Hameeda et al., 2008; Souchie et al., 2006; Murty and Ladha, 1988). Considering that $P$ availability is a limiting step in plant nutrition, this evidence suggests a fundamental contribution of phosphate-solubilizing bacteria to plant nutrition and, therefore, to the improvement of plant growth performance. Inoculation of rice (Oryza sativa L.) seeds with Azospirillum lipoferum strain $34 \mathrm{H}$ increased the phosphate ion content and resulted in significant improvement of root length and shoot dry matter (Murty and Ladha, 1988). Hameeda et al. (2008) verified that the seed inoculation with Pseudomonas niger strain CDB 35 (an isolate with high $\mathrm{P}$ solubilization potential) increased the grain yield of maize by $64 \%$ compared to the uninoculated control. Strains of phosphate solubilizing bacteria promoted increased $\mathrm{P}$ uptake by the mung bean plants [Vigna radiata (L.) Wilczek], improving the performance of plant growth (Walpola and Yoon, 2013).

Phosphorus fertilization significantly affected the stem diameter, number of leaves per plant, leaf area, leaf dry matter and stem plus leaf sheath dry matter. The seed inoculation with diazotrophic bacteria did not affect these variables (Table 2). For relative chlorophyll content measured through SPAD readings at 21 DAS, root volume and root dry matter, there was significant interaction between phosphorus fertilization and inoculation of maize seeds with diazotrophic bacteria.
Phosphorus fertilization increased the number of leaves per plant, stem diameter, leaf area, leaf dry matter and stem plus leaf sheath dry matter of maize plants by 12 , $33,49,53$ and $59 \%$, respectively, compared to the treatment without $\mathrm{P}$ fertilization (Table 3 ). Phosphorus and nitrogen are important macronutrients for growth and development of plants. Phosphorus is a component of the complex nucleic acid structure of plants, which regulates protein synthesis. This element is also associated with complex energy transformations in the plant and components of cell membranes. Phosphorus is, therefore, important in cell division and development of new tissue (Taiz and Zeiger, 2013). These functions of $P$ in plants justifies the positive results in the biometric variables, observed in this study (Table 2 ).

With the addition of phosphate fertilizer, the inoculation with the combination of the two bacteria strains (A. brasilense and $H$. seropedicae) showed higher root volume $\left(247.5 \mathrm{~cm}^{3}\right.$ pot $\left.^{-1}\right)$ compared to the uninoculated control $\left(142.5 \mathrm{~cm}^{3}\right.$ pot $\left.^{-1}\right)$, but no significant difference (Figure 2a). In the absence of phosphate fertilizer, the inoculation of $H$. seropedicae resulted in smaller root volume compared to the uninoculated control. The inoculation with two bacteria strains ( $A$. brasilense and $H$. seropedicae) associated to phosphorus fertilization provided higher root volume compared to the inoculation in the absence of phosphate fertilizer. Phosphorus deficiency can lead to nutritional imbalance of plants, such as in the Ca/P ratio (Novais et al., 2007). This nutritional imbalance could affect the composition of cell wall and tissues and therefore the growth and development of maize plants.

Inoculation with combination of the two bacteria strains ( $A$. brasilense and $H$. seropedicae) as affected by phosphorus fertilization showed higher root dry matter compared to the uninoculated control (Figure 2b). In turn, when there was no addition of phosphate fertilizer, inoculation of the two bacteria strains resulted in less root dry matter compared to the uninoculated control. These data indicate that the phosphorus fertilization favored diazotrophic bacteria inoculation in relation to the 

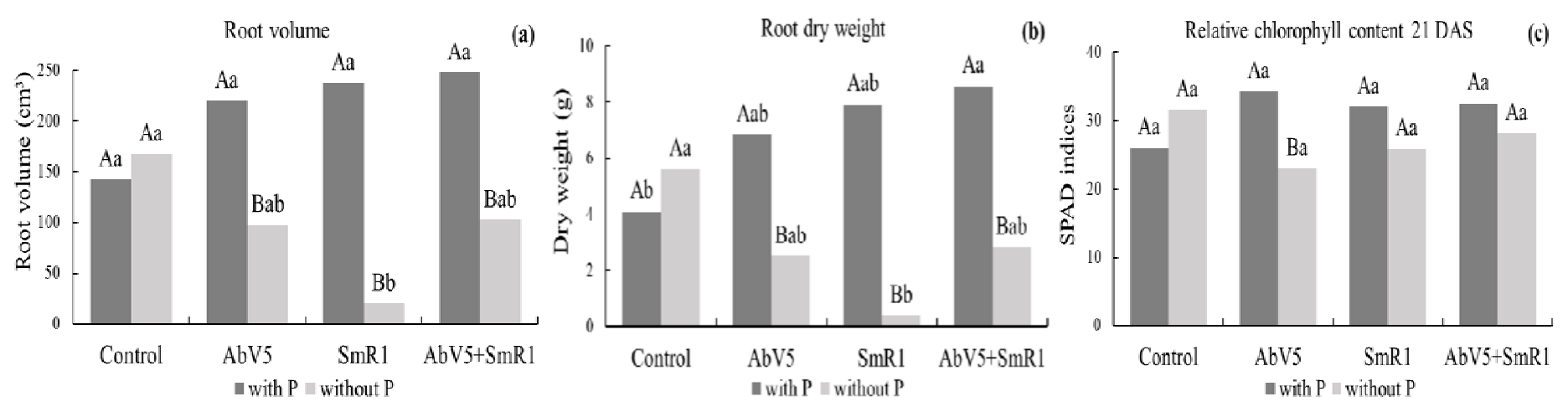

Figure 2. Root volume (a), root dry weight (b) and relative chlorophyll content (c) 21 days after sowing maize hybrid seed via $30 \mathrm{~F} 53 \mathrm{H}$ inoculated with plant growth promoting bacteria as a function of phosphate fertilizer ${ }^{1}$. ${ }^{1}$ Means followed by the same letter UPPERCASE comparing phosphorus fertilization in seed inoculation, LOWERCASE comparing seed inoculation in phosphate fertilizer, not differ significantly by the Tukey test at $5 \%$.

Table 3. Stem diameter (SD), number of leaves (NL), leaf area (LA), leaf dry weight (LDW) and stem+sheaths dry weight (SSDW) of maize plants inoculated via 30F53H hybrid seed with plant growth promoting bacteria as a function of phosphate fertilizer ${ }^{1}$.

\begin{tabular}{lccccc}
\hline $\mathbf{P}$ & SD $(\mathbf{m m})$ & $\mathbf{N L}$ & LA $\left(\mathbf{d m}^{2}\right)$ & LDW $(\mathbf{g})$ & SSDW $(\mathbf{g})$ \\
\hline With & $17.39^{\mathrm{a}}$ & $7.46^{\mathrm{a}}$ & $6.96^{\mathrm{a}}$ & $9.18^{\mathrm{a}}$ & $10.52^{\mathrm{a}}$ \\
Without & $11.59^{\mathrm{b}}$ & $6.52^{\mathrm{b}}$ & $3.57^{\mathrm{b}}$ & $4.34^{\mathrm{b}}$ & $4.32^{\mathrm{b}}$ \\
Average & $14.49^{\star *}$ & $6.99^{\star}$ & $5.27^{* *}$ & $6.75^{* *}$ & $7.42^{\star *}$ \\
\hline C.V. (\%) & 29.32 & 17.96 & 46.16 & 46.97 & 62.75 \\
L.S.D. & 3.12 & 0.92 & 1.79 & 2.33 & 3.42 \\
\hline
\end{tabular}

${ }^{1}$ Means followed by the same lowercase letters (column) do not differ by Tukey's test $(p>0.05)$. ${ }^{*}=P \leq 0.05 ;{ }^{*}=P \leq 0.01$; ns $=$ Not significant, by Tukey's test Fisher-Snedecor.

development of the maize root system, especially when the two strains were inoculated in combination. This result indicates that the phosphate solubilization promoted by diazotrophic bacteria (Jain et al., 2010) can improve the use efficiency of this nutrient.

Dartora et al. (2013) evaluated the effects of diazotrophic bacteria inoculation associated with nitrogen fertilization, and found positive influence when maize plants were inoculated with $A$. brasilense and $H$. seropedicae, resulting in increased stem diameter, shoot dry matter and grain yield of up to $7 \%$ compared to the uninoculated control. Similarly, Lana et al. (2012) observed increase in maize grain yield from 7 to $15 \%$, using the seed inoculation with $A$. brasilense. The genera Azospirillum and Herbaspirillum, due to the preference of colonization in local distinct of the plants, and the inoculation of two strains $(A$. brasilense and $H$. seropedicae) may have favored the nutrient assimilation in the presence of available $\mathrm{P}$, improving the translocation and distribution of nutrients in the plant, and consequently the maize development.

The relative chlorophyll content in the maize leaves measured through SPAD readings at 21 DAS, showed interaction between the factors studied, differing only when there has been inoculation of $A$. brasilense, and the highest relative chlorophyll content was obtained when maize plants were fertilized with $P$ (Figure 2c). The increase in the relative chlorophyll content to phosphate fertilization may be associated with the production of phytohormones due to the bacterial activity, such as auxin and gibberellin (Strzelczyk et al., 1994). In a recent study, Baldotto et al. (2012) found that maize plants inoculated with diazotrophic bacteria or phosphate solubilizing bacteria showed higher concentrations of nitrogen, phosphorus and potassium in the leaf tissue, resulting in the higher plant growth and increase of the SPAD index. The phosphorus fertilization and maize seed inoculation with $A$. brasilense and $H$. seropedicae did not affect the leaf gas exchange parameters related to photosynthesis and respiration of corn plants. There was effect of $P$ fertilization only for the intercellular $\mathrm{CO}_{2}$ concentration $(\mathrm{Ci})$ and water-use efficiency (WUE) on the assessment performed during the photosynthetically active leaves (10:00 a.m.), and for the leaf $\mathrm{CO}_{2}$ assimilation rate $(A)$ in the period of plant respiration at 10:00 p.m. (Table 4 and Figure 3). 
Table 4. Summary of analysis of variance performed for gas exchange during photosynthesis (10:00 a.m.) and respiration (10:00 p.m.) on maize leaves, rate of net $\mathrm{CO}_{2}$ assimilation $(A)$, leaf transpiration $(E)$, stomatal conductance $\left(g_{s}\right)$ and the water-use efficiency $(W U E)$ from the leaves of plants inoculated via 30F53H hybrid corn seed with plant growth promoting bacteria as a function of phosphate fertilizer ${ }^{1}$.

\begin{tabular}{|c|c|c|c|c|c|}
\hline \multirow{2}{*}{$\begin{array}{l}\text { Source of } \\
\text { variation }\end{array}$} & $A\left(\mu \mathrm{mol} \mathrm{CO} \mathrm{Cm}^{-2} \mathrm{~s}^{-1}\right)$ & $g_{s}\left(\mathrm{~mol} \mathrm{~m}^{-2} \mathrm{~s}^{-1}\right)$ & $E\left(\mathrm{mmol} \mathrm{H}_{2} \mathrm{O} \mathrm{m}^{-2} \mathrm{~s}^{-1}\right)$ & $C i\left(\mathrm{mmol} \mathrm{m}^{-2} \mathrm{~s}^{-1}\right)$ & WUE \\
\hline & \multicolumn{5}{|c|}{ Mean square (10:00 am) } \\
\hline $\mathrm{P}$ fertilization & $5.355^{\text {ns }}$ & $0.003^{\text {ns }}$ & $3.421^{\text {ns }}$ & $11021.084^{*}$ & $1.164^{* *}$ \\
\hline Inoculation & $12.176^{\mathrm{ns}}$ & $0.004^{\mathrm{ns}}$ & $1.151^{\mathrm{ns}}$ & $1548.705^{\mathrm{ns}}$ & $0.162^{\mathrm{ns}}$ \\
\hline Interaction & $28.292^{\mathrm{ns}}$ & $0.002^{\text {ns }}$ & $0.747^{\text {ns }}$ & $946.880^{\mathrm{ns}}$ & $0.197^{\mathrm{ns}}$ \\
\hline Residual & 24.620 & 0.005 & 1.343 & 1487.735 & 0.110 \\
\hline C.V. (\%) & 18.59 & 44.46 & 20.47 & 85.39 & 7.00 \\
\hline \multirow[t]{2}{*}{ Average } & 26.69 & 0.16 & 5.66 & 45.17 & 4.75 \\
\hline & \multicolumn{5}{|c|}{ Mean square $(10: 00 \mathrm{pm})$} \\
\hline $\mathrm{P}$ fertilization & $1.371^{*}$ & $0.000^{\text {ns }}$ & $0.022^{\text {ns }}$ & $19589.874^{\mathrm{ns}}$ & $8.367^{\text {ns }}$ \\
\hline Inoculation & $0.063^{\text {ns }}$ & $0.000^{\mathrm{ns}}$ & $0.004^{\mathrm{ns}}$ & $7739.199^{\text {ns }}$ & $6.542^{\text {ns }}$ \\
\hline Interaction & $0.448^{\text {ns }}$ & $0.000^{\mathrm{ns}}$ & $0.001^{\mathrm{ns}}$ & $25679.297^{\text {ns }}$ & $7.256^{\mathrm{ns}}$ \\
\hline Residual & 0.255 & 0.000 & 0.009 & 36059.995 & 21.318 \\
\hline C.V. (\%) & 18.52 & 37.52 & 35.42 & 21.08 & 42.33 \\
\hline Average & 2.73 & 0.01 & 0.28 & 900.82 & 10.91 \\
\hline
\end{tabular}

${ }^{1 *}=\mathrm{P} \leq 0.05 ;{ }^{* *}=\mathrm{P} \leq 0.01 ; \mathrm{ns}=$ Not significant, by Tukey's test Fisher-Snedecor.

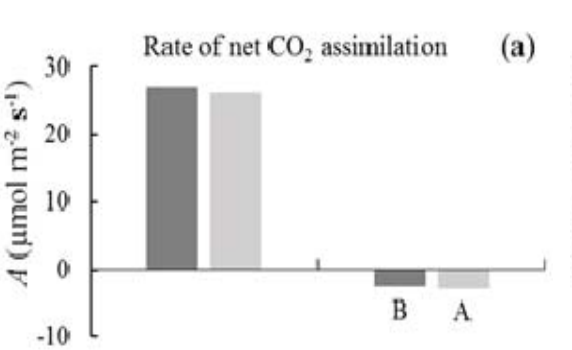

10:00 a.m. $\quad 10 ; 00 \mathrm{p}, \mathrm{m}$.
= with $\mathrm{P}=$ without $\mathrm{P}$

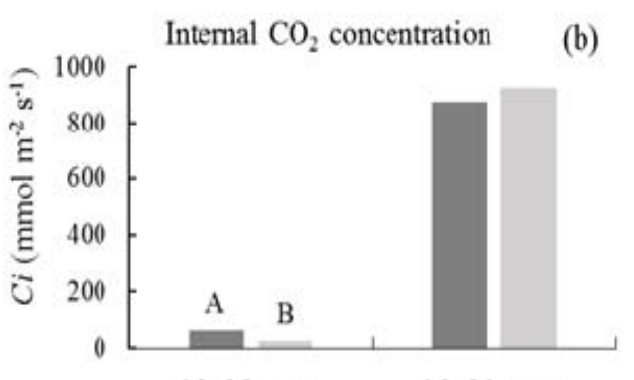

10:00 a.m. $\quad$ 10:00 p.m.

with $\mathrm{P}=$ without $\mathrm{P}$

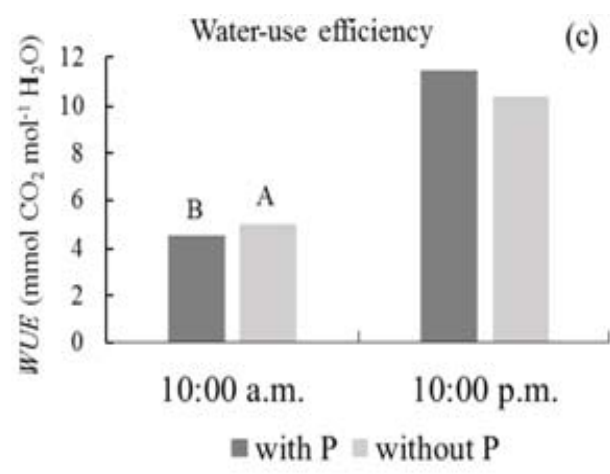

Figure 3. Measures of $\mathrm{A}=$ rate of net $\mathrm{CO}_{2}$ assimilation (a); $\mathrm{Ci}=$ internal $\mathrm{CO}_{2}$ concentration (b) and EUA = water-use efficiency (c), at 10:00 a.m. and 10:00 p.m. from the leaves of plants inoculated via 30F53H hybrid corn seed with plant growth promoting bacteria as a function of phosphate fertilizer.

The evaluation of the $A$ measured at 10:00 p.m. showed to be higher for respiration rate when maize plants were not fertilized with phosphorus (Figure 3a). Intercellular $\mathrm{CO}_{2}$ concentration measured at 10:00 h showed higher value when plants were fertilized with phosphorus (Figure 3b). In turn, the water use efficiency of maize plants showed higher values in the soil devoid of phosphate fertilization (Figure 3c).

One of the main factors that interfere with photosynthesis and leaf transpiration is the difference in the gradient of $\mathrm{CO}_{2}$ gas and water between the internal and external environment of the leaves (Cowan and Troughton, 1971). The stomata possess the function of intermediating these gas exchanges with opening and stomatal conductance, which is originated by water potential (Farquhar and Raschke, 1978). In this sense, adequate water supply as the crop needs, may have favored similar stomatal behavior of leaf tissue of maize plants.

\section{Conclusion}

Phosphorus fertilization improved growth and development of maize plants, regardless of seed inoculation with diazotrophic bacteria. The inoculation with $A$. brasilense and $H$. seropedicae improved the root and shoot growth of maize plants, indicating increase in 
the phosphorus solubilization or higher phosphorus use provided by the plant root system.

Seed inoculation with $A$. brasilense associated with phosphorus fertilization enhances the relative chlorophyll content, resulting in higher metabolic structure to the photosynthetic activity of maize plants.

\section{Conflict of Interest}

The author(s) have not declared any conflict of interest.

\section{ACKNOWLEDGEMENTS}

For Coordination of Improvement of Higher Education Personnel (CAPES) and the National Postdoctoral Program (PNPD), the granting of scholarships and the National Council for Scientific and Technological Development (CNPq), INCT - Biological Nitrogen Fixation in Grasses and Araucaria Foundation for Scientific and Technological Development of Paraná (Araucaria Foundation) for financial support.

\section{REFERENCES}

Alvarez VVH, Fonseca DM (1990). Definition of phosphorus levels to determine the phosphate maximum adsorption capacity and the response curves for greenhouse experiments. R. Bras. Cienc. Solo 14(1):49-55.

Baldani JI, Baldani VLD, Seldin, I, Döbereiner, J (1986). Characterization of Herbaspirillum seropedicae gen. nov., sp. nov., a root-associated nitrogen-fixing bacterium. Int. J. Syst. Bacteriol. Baltimore 36(1):86-93. http://dx.doi.org/10.1099/00207713-36-1-86

Baldani JI, Baldani VLD (2005). History on the biological nitrogen fixation research in graminaceous plants: Special emphasis on the Brazilian experience. An. Acad. Bras. Cienc. 77(3):549-579. http://dx.doi.org/10.1590/S0001-37652005000300014

Baldotto LEB, Silva LGJ, Canellas LP, Olivares F L, Baldotto MA (2012). Initial growth of maize in response to application of rock phosphate, vermicompost and endophytic bacteria. Rev. Ceres 59(2):262-270. http://dx.doi.org/10.1590/S0034-737X2012000200016

Carvalho DDC, Oliveira DF, Pasqual M, Campos VP (2009). Plant growth promoter producing rhizobacteria. Pesquisa Agropecuária Tropical, 39(4):338-341. Disponível em: http://www.revistas.ufg.br/index.php/pat/article/view/3947. Acessado em:10 jul. 2014

Coelho AM, França GE de, Bahia Filho AFC. (2006). Nutrição e adubação do milho. Disponível em: http://www.cnpms.embrapa.br/publicacoes/publica/2006/circular/Circ 78.pdf. Acessado em: 10 jul. 2014.

CŌNAB - Companhia Nacional de Abastecimento (2014). Indicadores da Agropecuária. Bras. Ano 22(4):90. Disponível em: http://www.conab.gov.br/OlalaCMS/uploads/arquivos/14_04_30_11_ 38_00_revista_abril_versao_final.pdf. Acessado em: 10 jul. $20 \overline{1} 4$.

Cowan IR, Troughton ${ }^{-} \mathrm{JH}$ (1971). The relative role of stomata in transpiration and assimilation. Planta, Berlin 97(4):325-336. http://dx.doi.org/10.1007/BF00390212.

Dartora J, Guimarães VF, Marini D, Sander G (2013). Nitrogen fertilization associated to inoculation with Azospirillum brasilense and Herbaspirillum seropedicae in the maize. Rev. Bras. Engenharia Agríc. Ambiental Campina Grande 17(10):1023-1029. http://dx.doi.org/10.1590/S1415-43662013001000001.

Döbereiner J, Baldani VLD, Baldani JI (1995). Como isolar e identificar bactérias diazotróficas de plantas não-leguminosas. Itaguaí: Embrapa - CNPAB P. 60.
Döbereiner J (1953). Azotobacter em solos ácidos. Bol. Inst. Ecol. Exp. Agr. 11:1-36.

Döbereiner J (1966). Azotobacter paspali sp. nov., uma bactéria fixadora de nitrogênio na rizosfera de Paspalum. Pesq Agropec Bras $1: 357-365$ Disponivel em: http://seer.sct.embrapa.br/index.php/pab/article/view/18041> Acesso em: 11 de jun. 2014.

Döbereiner J, De-Polli H (1980). Diazotrophic rhizocoenoses. Stewart D. P. \& Gallon, J. R., ed. Nitrogen fixation. London: Academic Press, 1:301-334.

Döbereiner J, Ruschel AP (1958). Uma nova espécie de Beijerinkia. Rev. Biol. 1:261-272.

EMBRAPA (2013). Empresa Brasileira de Pesquisa Agropecuária. Sistema brasileiro de classificação de solos. 3rd ed. Bras. EMBRAPA P. 353.

Farquhar GD, Raschke K (1978). On the resistance to transpiration of the sites of evaporation within the leaf. Plant Physiology, Lancaster, 60(6):1000-1005. Disponivel em: <http://www.ncbi.nlm.nih.gov/pubmed/16660404> Acesso em: 12 de jun. 2014.

Ferreira DF (2011). Sisvar: A computer statistical analysis system. Cienc. Agrotecnol. 15(6):1039-1042. http://dx.doi.org/10.1590/S141370542011000600001.

IBGE - Instituto Brasileiro de Geografia e Estatística (2014). Disponível em:

http://www.ibge.gov.br/estadosat/temas.php?sigla=pr\&tema=lavourat emporaria2011] Acesso em: 10 jul. 2014.

Jain R, Saxena J, Sharma V. (2010). The evaluation of free and encapsulated Aspergillus awamori for phosphate solubilization in fermentation and soil-plant system. Appl. Soil Ecol. 46(1):90-94. http://dx.doi.org/10.1016/j.apsoil.2010.06.008.

Lana M do C, Dartora J, Marini D, Hann JEH (2012). Inoculation with Azospirillum, associated with nitrogen fertilization in maize. Rev. Ceres 59(13):399-405. http://dx.doi.org/10.1590/S0034737X2012000300016.

Marcos Filho J (2005). Fisiologia de sementes de plantas cultivadas. Piracicaba: Fealq P. 495.

Novais RF, Smyth TJ, Nunes FN (2007). Fósforo. In: Novais R.F., Alvarez V.H., Barros N.F., Fontes R.L.F., Cantarutti R.B., Neves J.C.L. (Eds.) /Fertilidade do solo. Viçosa: Soc. Bras. Ciênc. Solo pp. 471-550.

Rodrigues LFOS, Guimarães VF, Silva MB, Pinto Jr AS, Klein J, Costa ACPR (2014). Características agronômicas do trigo em função de Azospirillum brasilense, ácidos húmicos e nitrogênio em casa de vegetação. Rev. Bras.Engenharia Agríc. Ambiental, Campina Grande 18(1):31-37. http://dx.doi.org/10.1590/S1415-43662014000100005.

Strzelczyk E, Kamper M, LI C. (1994). Cytokinin-like-substances and ethylene production by Azospirillum in media with different carbon sources. Microbiol. Res. 149(1):55-60. http://dx.doi.org/10.1016/S0944-5013(11)80136-9.

Strzelczyk E, Pokojska-Burdziej A (1984). Production of auxins and gibberellin-like substances by mycorrhizal fungi, bacteria and actinomycetes isolated from soil and the mycorrhizosphere of pine $\begin{array}{llll}\text { (Pinus silvestris } & \text { L.). } & \text { Plant } & \text { Soil }\end{array}$ http://dx.doi.org/10.1007/BF02197150.

Taiz L, Zeiger E (2013). Assimilação de Nutrientes. In: Taiz, L.; Zeiger, E. Fisiologia Vegetal. Porto Alegre: Artmed P. 918.

USDA - United States Department of Agriculture. (2014). Wold Agricultural Supply and Demand Estimates. Disponível em: <www.usda.gov/oce/commodity/wasde/index.htm>. Acesso em: 22 mai. 2014.

Walpola BC, Yoon MH (2013). Phosphate solubilizing bacteria: Assessment of their effect on growth promotion and phosphorous uptake of mung bean (Vigna radiata [L.] R. Wilczek). Chilean J. Agric. Res. $\quad 73(3): 275-281 . \quad h t t p: / / d x . d o i . o r g / 10.4067 / S 0718$ 58392013000300010

Murty MG, Ladha JK (1988). Influence of Azospirillum inoculation on the mineral uptake and growth of rice under hydroponic conditions. Plant Soil 108(2):281-285. http://dx.doi.org/10.1007/BF02375660

Souchie EL, Saggin Jr OJ, Silva EMR, Campello EFC, Azcón R, Barea JM (2006). Communities of P-solubilizing bacteria, fungi and arbuscular mycorrhizal fungi in grass pasture and secondary forest of 
Paraty, RJ-Brazil. Anais da Academia Brasileira de Ciências, 78(1):183-193. http://dx.doi.org/10.1590/S000137652006000100016.

Hameeda B, Harini G, Rupela OP, Wani SP, Reddy G (2008). Growth promotion of maize by phosphate-solubilizing bacteria isolated from composts and macrofauna. Microbiol. Res. 163(2):234-242. http://dx.doi.org/10.1016/j.micres.2006.05.009. 